\title{
PHYSICIAN KNOWLEDGE AND RESPONSIBILITY OF PRESCRIPTION POLICY
}

\author{
Pengetahuan dan Tanggung Jawab Dokter Terhadap Kebijakan Peresepan Obat \\ Isna Rahmawati ${ }^{1},{ }^{*}$ Venia IIma Dwi Prastika ${ }^{1}$ \\ ${ }^{1}$ Department of Health Services Research and Policy \\ Research School of Population Health, Faculty of Public Health, Universitas Airlangga, Indonesia \\ *Correspondence: venia.ilma.dwi-2015@fkm.unair.ac.id
}

\begin{abstract}
Background: The minimum standard of generic prescription drugs at a hospital is at $90 \%$. However, the preliminary study discovered the use of generic drugs at Kalisat District Hospital, Jember from 2009 to 2011 was amounted to $57.50 \%$, while the use of patent medicines was at $42.50 \%$. This difference indicates unachieved standard of generic prescription drugs at the Hospital.

Aims: This study identified doctors' knowledge and responsibility of drug prescription policy at Kalisat District Hospital.

Methods: This descriptive and observational study employed a cross-sectional design. The data were collected randomly from 50 prescription documents of Kalisat District Hospital, Jember from April to July 2013. This study involved 6 general practitioners, 2 dentists, and 4 specialists.

Results: There was a strong correlation between doctors' specialization and responsibility for pescribing generic drugs. Doctors' knowledge about prescription policy of generic drugs was still lacking at 58.3\%, while doctors' responsibility for prescribing generic drugs was satisfying.

Conclusion: Doctors at Kalisat District Hospital have an excellent sense of responsibility in prescribing generic drugs even though they have insufficient knowledge. The Hospital should conduct trainings, provide incentives, improve policies, monitor and evaluate generic prescriptions.
\end{abstract}

Keywords: generic drugs, prescription, doctors' responsibility, doctors' knowledge.

\begin{abstract}
ABSTRAK
Latar Belakang: Standar minimal peresepan obat generik di rumah sakit adalah sebesar 90\%. Namun, penelitian pendahulu menunjukkan penggunaan obat generik di RSD Kalisat Jember pada tahun 2009-2011 sebesar $57,50 \%$ dan penggunaan obat paten sebesar $42,50 \%$. Perbedaan ini menunjukkan belum tercapainya standar dari peresepan obat generik di rumah sakit.

Tujuan: Penelitian ini mengidentifikasi pengetahuan dan tanggung jawab dokter terhadap kebijakan penulisan resep obat generik di rumah sakit.

Metode: Penelitian ini merupakan penelitian deskriptif dan observasional serta menggunakan studi crosssectional. Data dikumpulkan dari 50 dokumen resep RSD Kalisat Jember secara acak pada April-Juli 2013. Penelitian ini mengambil sampel 6 dokter umum, 2 dokter gigi dan 4 dokter spesialis.

Hasil: Ada hubungan yang kuat antara spesialisasi dokter dan tanggung jawab mereka dalam peresepan obat generik. Pengetahuan dokter terhadap kebijakan peresepan obat generik di rumah sakit masih kurang sebesar $58,3 \%$, sedangkan tanggung jawab dokter terhadap peresepan obat generik sudah baik.

Kesimpulan: Dokter di RSD Kalisat Jember telah memiliki tanggung jawab yang baik terhadap peresepan obat generik walaupun mereka memiliki pengetahuan yang masih kurang. Rumah sakit diharapkan dapat mengadakan pelatihan, memberikan insentif, memperbaiki kebijakan, serta mengadakan monitoring dan evaluasi terhadap penulisan resep obat generik oleh dokter.
\end{abstract}

Kata Kunci: obat generik, peresepan obat, tanggung jawab dokter, pengetahuan dokter.

\section{INTRODUCTION}

Concerning Pharmaceutical Service Standard at hospitals, the Regulation of Indonesian Ministry of Health Number 72 of 2016 defines pharmaceutical care as a direct healthcare service for providing pharmaceutical service to ensure the quality of patients' life. Pharmaceutical care contributes to developing a vast and 
well-coordinated pharmaceutical service for hospital units, including a diagnosis and therapy unit, nursing unit, medical staff unit, and so forth.

Pharmaceutical care has to be affordable for all social classes. The most significant component that affects medication cost is the availability of drugs, contributing $70 \%$ of the cost. Consequently, the Indonesian Government provides generic drugs with reasonable quality assurance, affordable prices, and high availability for patients. Drugs become an essential aspect of maintaining people's health and wellbeing. Most of the medical interventions use drugs, and thus the prominent availability of various drugs is necessary.

In spite of efficacy and good quality, drug prices have to be reasonably standardized for every social class. Generic drugs are one of the efforts made by the pharmacy care to provide drugs for all. According to the Regulation of Indonesian Ministry of Health Number 2 of 2010 concerning obligations to use generic drugs in healthcare facilities, generic drugs are medicine which its official name of International NonProprietary Names (INN) is appointed in Indonesian Pharmacopeia or other standard books about drug substances. Drugs must have an essential indication as a health logistic that is acceptable and has good quality to be safely consumed by the community. Generic drugs are drugs with good quality and affordable prices that can be obtained by all social classes.

Medicines are the most significant components of medical service cost in Indonesia. Even though the consumption level of drugs in Indonesia is relatively low, the cost is relatively high. Hence, the Government issued a policy to utilize generic drugs instead to maintain the welfare of medical service providers, especially owned by the Government. Increasing the use of generic drugs may further decrease costs of medicare beneficiaries and plans while also generating clinical benefits. For example, the cost savings generated by generic drug substitution have been attributed to an increase in medication adherence which may improve clinical outcomes (Hohmann et al., 2018).

However, there are some doctors and patients that assume generic drugs as cheap and low-quality drugs. This matter is due to the fact that generic drugs are imitation (clone) of drugs that exceed their expiration date and are promoted using the name of active substances in branded drugs. Ferrerria et al. (2017) investigated the moderating roles of economic crisis in consumer behavior towards generic drugs by evaluating four correlations, such as (i) perceived quality, (ii) past consumption of generic drugs, (iii) recommendations of health care providers in relation to expenditure, and (iv) intention to purchase generic drugs. The results of the structural equation model show that in the economic crisis, consumers who prefer generic drugs have firm purchase intentions. Similarly, attitudes to expenditure is positively influenced by perceived quality and prior experience. Moreover, the probability of choosing generic drugs is generally higher for those who have attached more to their prior experience and perceived quality of generic drugs.

Deriving from the previous studies, to increase the utilization of generic drugs, some evaluations, along with proper education regarding generic drugs, are required for the community. According to the Regulation of the Indonesian Ministry of Health Number 2 of 2010, doctors assigned in healthcare facilities need to prescribe generic drugs for every patient based on the medical indication. Doctors are responsible for patients' safety, starting from a physical examination to prescription for patients. Moreover, 
doctors have to obey prescription policy of generic drugs at hospitals.

Prescription policy of generic drugs is a legitimate authority, and thus there is no reason for someone to disobey. The Government has issued a policy regarding generic drug supplies at public hospitals. Based on the Regulation of the Indonesian Ministry of Health Number 2 of 2010 regarding obligations to use generic drugs in healthcare facilities, public healthcare providers are required to provide generic drugs for outpatients and inpatients in accordance to the formularies. Rising healthcare costs in an uncertain global economic situation can increase the use of generic drugs by the Government and buyers. Kaplan et al. (2012) revealed that price surveys in 36 Low and MiddleIncome Countries (LMICs) showed that in the private sectorthe low cost of generic drugs is 2.6 times cheaper than the corresponding originator drugs. By using generic drugs, potential savings can be quite large. For example, in the private sector in 17 countries, the percentage of average savings for individual drugs $(\mathrm{n}=4$ 12 drugs) will range from $9 \%$ to $89 \%$ if buyers switch from the originator brands to the cheapest generic equivalents. However, savings will not be confirmed to the private sector (Kaplan et al., 2012).

More frequent use of generic drugs, which many countries in the world apply is a crucial step to reduce prescription drug costs. The availability of generic drugs at public hospitals can minimize drug procurement costs which are usually expensive. Kotler et al. (2012) discovered that hospitals can increase profits by giving generic drugs to patients. In addition, generic drugs have good quality and are affordable for all social classes so that the Government is expected to expand the use of generic drugs, especially at public hospitals.

To enhance equitable drug distribution and affordable drug prices by wider community, the Government has launched the Generic Medication program. There are guidelines and supervision of generic drug use in public healthcare facilities as determined in the Decree of the Indonesian Ministry of Health Number 159 of 2010. These aim to ascertain and supervise hospitals to use appropriate generic drugs. The Decree of the Indonesian Ministry of Health Number 159 of 2010 also states that the formulary protocol can easily monitor and evaluate prescription for generic drugs at hospitals.

With an increase in drug prescription and rising drug costs, the use of generic drugs is on demands now (Howard et al., 2018). Generic drugs are alternatives issued by the Government to suppress drug costs so that poor community can afford to buy drugs and take their rights. The researchers need to develop explanatory theories of drug policy formulation (Burris, 2017). Prescription policy of generic drugs ensures that healthcare providers can give the best service for patients, for instance providing appropriate drugs. The availability of excellent and affordable drugs is a must for every healthcare provider.

According to Krisnadewi, Subagio, and Wiratmo (2014), prescription is doctors' expertise of healthcare services that applies knowledge and skills both in apothecary and therapy which are done precisely, safely and rationally to patients and the entire community. In this case, generic prescription applies to public hospitals. Doctors working at public hospitals are required to comply with generic prescribing rules and standards amounting to $90 \%$ for districts and cities as determined by the Government. The Decree of the Indonesian Directorate General of Pharmaceutical and Medical Devices Number 02.03 of 2014 describes national formulary as a list of selected drugs required and provided in healthcare facilities which become guides for 
executing National Health Insurance. Doctors are responsible for the formulary which prioritizes the utilization of generic drugs over patent drugs.

Doctors' responsibility is vital for the brand's safety. Furthermore, doctors as human resources are accountable for the quality and continuity of medical services at hospitals. Responsibility of generic prescription issued by the Government is obligatory not only for general practitioners but also for dentists and medical specialists. Generic drugs are alternatives distributed by the Government to reduce drug costs which are the most significant component of healthcare costs. This study aimed to identify doctors' knowledge and responsibility of generic prescription policy at Kalisat District Hospital.

\section{METHOD}

This study was a descriptive observational since it utilized questionnaires to collect data. This study employed a cross-sectional design in which data collection was conducted at one time at Kalisat District Hospital, Jember from April to July 2013. With a total sampling technique, there were 12 samples, including 6 general practitioners, 2 dentists, and 4 medical specialists, i.e., 1 neurologist, 1 gynecologist, 1 anesthesiologist, and 1 orthopedist.

The primary data were obtained from questionnaires developed with obedience theory by Sarwono (2009) and distributed to 12 functional doctors at Kalisat District Hospital. In addition, the data were randomly taken from 50 prescription documents out of 4014 documents from Medical Record Unit.

Meanwhile, hospital profiles and annual hospital reports were used to collect the secondary data. The variables observed include doctors' characteristics (gender, age, knowledge, and specialization), doctors' knowledge, and doctors' responsibility for prescribing generic drugs at the Hospital. The data were analyzed descriptively with frequency distribution, percentage of doctors' characteristics, doctors' comprehension, and doctors' responsibility for generic prescriptions.

\section{RESULTS AND DISCUSSION}

\section{Respondents' Characteristics}

Respondents' characteristics are some factors that affect the final results of the study. Respondents' characteristics involve gender, age, and specialization. In terms of gender, 8 doctors $(66.7 \%)$ are male, and $33.3 \%$ of the doctors are female. Based on age, there are 6 doctors $(50 \%)$ which are under or 40 years old, and $50 \%$ of them are over 40 years old. According to specialization, $50 \%$ of the respondents are general practitioners, $16.7 \%$ of them are dentists, and $33.3 \%$ are specialists. It was found that destists completely implement generic prescription policy. Pearson Chi-Square score was obtained 4.875 with $\mathrm{p}=0.087$ and $\mathrm{r}=0.637$. It means there is a strong correlation between doctors' specialization and their responsibility for generic prescriptions. Dentists tend to prescribe more generic drugs than specialists and general practitioners.

\section{Doctors' Knowledge of Generic Prescription Policy}

Doctors' knowledge of generic prescription policy can be seen from their awareness of prescribing drugs under the formulary and the policy. This present study on doctors' knowledge of prescription indicated that the doctors understood prescription requirements according to the generic and patent formulary. However, the doctors were unaware of prescribing generic drugs. Doctors' knowledge was rated from 1 to 4 . Rate 4 is for knowledgeable doctors, Rate 
3 is for decently informed doctors, and Rate less than 3 is assigned to less informed doctors. The data provide information that 7 doctors were still uninformed about prescription policy.

People obey because they understand regulations and compulsions. In addition, prescription policy is a legitimate and binding authority. Thus, there is no reason for doctors to not comply with the policy. Knowledge of prescription policy matters for the doctors in any healthcare providers since it can rapidly optimize the use of generic drugs. Doctors' knowledge of prescription policy based on specialty category can be seen in Table 1.

Medical specialists were more informed about prescription policy than general practitioners and dentists. Most of the general practitioners and dentists were uninformed about the use of generic drugs and the standard of prescribing generic drugs. A study in Perak, Malaysia found an effective educational intervention for doctors to improve the rate of generic prescription. This study pointed out that by inviting doctors to an interactive lecture and giving them an educational booklet and a drug list, they could manage to improve their knowledge of generic drugs (Hassali et al., 2014). Consequently, trainings for for general practitioners and dentists can be more intensive since patients will seek treatments from general practitioners and dentists before going to medical specialists.

Doctors' comprehension of generic prescription at Kalisat District Hospital was still lacking due to the fact that Kalisat District Hospital did not enforce generic prescriptions to all patients. Only patients with public insurance are required to receive generic drugs because the formulary comes from the List of National Essential Drugs (DOEN). Furthermore, there is no standard of generic prescription applied at the Hospital. Thus, the doctors are more unaware of standard hospital prescription.

Positive attitude towards the importance of health information for patients is a significant predictor for improving patients' comprehension. Medical providers, who believe health information delivery important, can be more open in learning about information delivery and approaches to support patients' comprehension of health information. Providing generic drug information becomes doctors' responsibilities to ensure patients' welfares. Toverud, Hartmann and Ha konsen (2015) highlighted that generic drugs are believed as a tool for better equity and access to drugs. By this means, it is assumed that patients can obtain their welfare as proper as possible. Moreover, doctors' comprehension in prescribing generic drugs need to improve according to pharmaceutical service standards as determined by the Government.

\section{Doctors' Responsibility for Generic Prescription Policy}

To prescribe drugs, doctors are responsible for following the formulary and generic prescription policy to patients. Table 2 explains doctors' responsibility for prescribing drugs at the Hospital. Excellent responsibility is scored $12-16$, and decent responsibilityis scored 7-11. While, deficient responsibility has less than 7 scores. The results show that doctors' responsibility is good, meaning that they bear moral dimensions under patients' welfare. Table 3 illustrates doctors' responsibility based on specialty category. 
Table 1. Doctors' Knowledge about Prescription Policy at Kalisat District Hospital Based on Specialties.

\begin{tabular}{|c|c|c|c|c|c|c|c|c|c|}
\hline \multicolumn{2}{|c|}{ Policy Comprehension } & \multicolumn{2}{|c|}{$\begin{array}{c}\text { General } \\
\text { Practitioner } \\
\text { s }\end{array}$} & \multicolumn{2}{|c|}{ Dentists } & \multicolumn{2}{|c|}{$\begin{array}{c}\text { Medical } \\
\text { Specialist } \\
\text { s }\end{array}$} & \multicolumn{2}{|c|}{ Total } \\
\hline & & $\mathbf{n}$ & $\%$ & $\mathbf{n}$ & $\%$ & $\mathbf{n}$ & $\%$ & $\mathbf{n}$ & $\%$ \\
\hline \multirow{2}{*}{$\begin{array}{c}\text { Guided by Generic } \\
\text { Formulary }\end{array}$} & Aware & 4 & 66.7 & 2 & 100 & 4 & 100 & 10 & 83.3 \\
\hline & $\begin{array}{c}\text { Unawar } \\
\mathrm{e}\end{array}$ & 2 & 33.3 & 0 & 0 & 0 & 0 & 2 & 16.7 \\
\hline \multirow{2}{*}{$\begin{array}{c}\text { Guided by Supporting } \\
\text { Formulary }\end{array}$} & Aware & 5 & 83.3 & 2 & 100 & 4 & 100 & 11 & 91.7 \\
\hline & $\begin{array}{c}\text { Unawar } \\
\text { e }\end{array}$ & 1 & 16.7 & 0 & 0 & 0 & 0 & 1 & 8.3 \\
\hline \multirow[b]{2}{*}{ Generic Drug Usage } & Aware & 1 & 16.7 & 0 & 0 & 3 & 75 & 4 & 33.3 \\
\hline & $\begin{array}{c}\text { Unawar } \\
\mathrm{e}\end{array}$ & 5 & 83.3 & 2 & 100 & 1 & 25 & 8 & 66.7 \\
\hline \multirow{2}{*}{$\begin{array}{c}\text { Standard of Generic } \\
\text { Prescription }\end{array}$} & Aware & 2 & 33.3 & 0 & 0 & 2 & 50 & 4 & 33.3 \\
\hline & $\begin{array}{c}\text { Unawar } \\
\text { e }\end{array}$ & 4 & 66.7 & 2 & 100 & 2 & 50 & 8 & 66.7 \\
\hline
\end{tabular}

Table 2. Distribution of Doctors' Responsibility for Prescription Policy at Kalisat District Hospital.

\begin{tabular}{|c|c|c|c|c|c|c|c|c|c|c|}
\hline \multirow{2}{*}{$\begin{array}{c}\text { The Doctors' Responsibility } \\
\text { for Generic Drug } \\
\text { Prescribing Policy }\end{array}$} & \multicolumn{2}{|c|}{ Never } & \multicolumn{2}{|c|}{ Rare } & \multicolumn{2}{|c|}{ Often } & \multicolumn{2}{|c|}{ Always } & \multicolumn{2}{|c|}{ Total } \\
\hline & $\mathbf{n}$ & $\%$ & $\mathbf{n}$ & $\%$ & $\mathbf{n}$ & $\%$ & $\mathbf{n}$ & $\%$ & $\mathbf{n}$ & $\%$ \\
\hline $\begin{array}{l}\text { Using Formulary Guide for } \\
\text { Prescribing Drugs }\end{array}$ & 0 & 0 & 0 & 0 & 6 & 50 & 6 & 50 & 12 & $\begin{array}{c}10 \\
0\end{array}$ \\
\hline $\begin{array}{l}\text { Using Generic Formulary } \\
\text { Guide more than } \\
\text { Supporting Formulary }\end{array}$ & 1 & 8.3 & 0 & 0 & 8 & 66.7 & 3 & 25 & 12 & $\begin{array}{c}10 \\
0\end{array}$ \\
\hline Prescribing Generic Drugs & 0 & 0 & 0 & 0 & 9 & 75 & 3 & 25 & 12 & $\begin{array}{c}10 \\
0\end{array}$ \\
\hline $\begin{array}{llr}\text { Offering } & \text { Generic } & \text { Drugs } \\
\text { before } & \text { Distributing } & \text { to } \\
\text { Patients } & & \end{array}$ & 1 & 8.3 & 2 & $\begin{array}{c}16 . \\
7\end{array}$ & 7 & 58.3 & 2 & 16.7 & 12 & $\begin{array}{c}10 \\
0\end{array}$ \\
\hline
\end{tabular}

In Table 3, general practitioners, dentists and medical specialists have a great responsibility for implementing generic prescription policy. Responsibility is a self-actualization to achieve a goal. As doctors need to be responsible for patients' prescription, they need to adhere to the formulary which is more frequently used than supporting formularies and generic drugs. The doctors at Kalisat District Hospital were mostly well-informed and responsible for prescribing generic drugs according to given formulary. Their obedience to generic drugs attributes hospital rules which only gives generic drugs to patients with public insurances to maximize profits. Kalisat District Hospital only prescribed patent medicines for general patients. Disobedience to the formulary will affect the service quality at the Hospital, especially in the Pharmacy Unit (Krisnadewi, Subagio, and Wiratmo, 
2014). Doctors' responsibility is not limited to prescribe generic drugs based on the formulary, but it also screens prescriptions accuracy as patients need.

Table 3. Doctors' Responsibility for Generic Prescription at Kalisat Public Hospital Based on Specialty in July 2013.

\begin{tabular}{|c|c|c|c|c|c|c|c|}
\hline \multicolumn{2}{|c|}{ Responsibility for Prescription } & \multicolumn{2}{|c|}{$\begin{array}{c}\text { General } \\
\text { Practitioners }\end{array}$} & \multicolumn{2}{|c|}{ Dentists } & \multicolumn{2}{|c|}{$\begin{array}{c}\text { Medical } \\
\text { Specialists }\end{array}$} \\
\hline & & $\mathbf{n}$ & $\%$ & $\mathbf{n}$ & $\%$ & $\mathbf{n}$ & $\%$ \\
\hline \multirow{3}{*}{$\begin{array}{l}\text { Using Formulary Guide } \\
\text { for Prescribing Drugs }\end{array}$} & Aware & 3 & 50 & 2 & 100 & 1 & 25 \\
\hline & $\begin{array}{r}\text { Unawar } \\
\mathrm{e}\end{array}$ & 3 & 50 & 0 & 0 & 3 & 75 \\
\hline & Lacking & 0 & 0 & 0 & 0 & 0 & 0 \\
\hline \multirow{3}{*}{$\begin{array}{r}\text { Using Generic Formulary } \\
\text { Guide more than } \\
\text { Supporting Formulary } \\
\text { (Brand Drugs) }\end{array}$} & Aware & 0 & 0 & 1 & 50 & 2 & 50 \\
\hline & $\begin{array}{r}\text { Unawar } \\
\mathrm{e}\end{array}$ & 6 & 100 & 0 & 0 & 2 & 50 \\
\hline & Lacking & 0 & 0 & 1 & 50 & 0 & 0 \\
\hline \multirow{3}{*}{$\begin{array}{r}\text { Prescribing Generic } \\
\text { Drugs }\end{array}$} & Aware & 0 & 0 & 1 & 50 & 2 & 50 \\
\hline & $\begin{array}{r}\text { Unawar } \\
\mathrm{e}\end{array}$ & 6 & 100 & 1 & 50 & 2 & 50 \\
\hline & Lacking & 0 & 0 & 0 & 0 & 0 & 0 \\
\hline \multirow{3}{*}{$\begin{array}{r}\text { Offering Generic Drugs } \\
\text { before Distributing to } \\
\text { Patients }\end{array}$} & Aware & 0 & 0 & 1 & 50 & 1 & 25 \\
\hline & $\begin{array}{r}\text { Unawar } \\
\mathrm{e}\end{array}$ & 4 & 66.7 & 1 & 50 & 2 & 50 \\
\hline & Lacking & 2 & 33.3 & 0 & 0 & 1 & 25 \\
\hline
\end{tabular}

Irrational prescription can cause excessive waste and resistance to certain antibiotics if patients suffer from diseases caused by bacteria. Moreover, excessive drug utilization can cause disease complications. Rational and logical prescription can save medicine costs and avoid other diseases arising from doctors' mistakes and irrationality in prescribing drugs. Rational prescription according to Maxwell (2016) may be a great influence on cost-effectiveness, for example prescribing generic drugs instead of branded drug from the same class. This considers the limited resources in healthcare providers. It can also improve community health and thus concurrently increase the level of productivity.

Furthermore, doctors must ensure that they play a role in medication. Doctors who are not competent in prescription may cause malpractice. Types of drugs and the level of risks associated also affect nonmedical health workers' responsibility for prescription. Medicines will be considered highly risky if they potentially cause severe side effects or serious interactions with other drugs for high doses (Maddox et al., 2016). High-dose drugs can be dangerous for the patients so that not only doctors but also pharmacists need to properly prescribe drugs.

Beside doctors and other health workers, pharmaceutical staffs can be monitored through a Prescription Drug Monitoring Program (PDMP). In Washington, periodic research on the Prescription Drug Monitoring Program was conducted to observe registration for emergency medicine providers and other health workers. The results indicated that drug providers or healthcare service providers are instructed to register into PDMP rather than use it as a way to observe prescription practices. 
Nevertheless, several policies aim to reduce overdose opioid prescription (Sun et al., 2018). The results prove the effectiveness of registration madate and suggest potential approaches to increase PDMP that are consistent with experts' recommendations. First, registration to PDMP is required for all prescriptions (Greenwood-ericksen et al., 2016). Second, policymakers must consider PDMP as a mandatory before prescribing opioids. Third, logistical barriers in the use of PDMP must be minimized (Poon et al., 2016). A potential solution is to automate requests for PDMP and integrate data into existing Electronic Medical Record (EMR).

Prescription in Indonesia can be performed using Information and Management System. This system is developed by hospitals and the Government to provide convenient pharmaceutical care for patients. It can be used to monitor prescription practices which can be done quickly and taken back in case there are prescription errors.

\section{CONCLUSION}

This study draws some conclusions in terms of doctors' characteristics, knowledge, and responsibility for generic prescriptions. Firstly, doctors' specializations have a strong correlation with their responsibility for generic prescriptions. There are $58.3 \%$ doctors whose comprehension of generic prescription policy is lacking. Meanwhile, all dentists and medical specialists are more knowledgeable about the policy. In addition, $66.7 \%$ of general practitioners are less aware of the policy. In terms of responsibility, the doctors at Kalisat District Hospital have a very good responsibility of prescribing generic drugs.

Increasing the doctors' awareness and responsibility for generic prescription can be accomplished by implementing the standards issued by the Government.
Training about hospital policy, proper monitoring, and evaluation can be carried out to observe whether doctors have improved their knowledge and responsibility of prescribing generic drugs. In addition, Kalisat District Hospital can give incentives to increase doctors' responsibility of prescribing generic drugs.

\section{CONFLICT OF INTEREST}

The authors state that there is no conflict of interest for this article.

\section{REFERENCES}

Amalia, D. T. and Sukohar, A. (2014) 'Rational Drug Prescription Writing', JUKE, 4(7), pp. 22-30.

Burris, S. C. (2017) 'Theory and methods in comparative drug and alcohol policy research: Response to a review of the literature', International Journal of Drug Policy. Elsevier B.V., 41, pp. 126-131. doi: 10.1016/j.drugpo.2016.11.011.

Greenwood-ericksen, M. B. et al. (2016) 'Best Practices for Prescription Drug Monitoring Programs in the Emergency Department Setting: Results of an Expert Panel', Annals of Emergency Medicine. American College of Emergency Physicians, 67(6), pp. 755-7764. doi: 10.1016/j.annemergmed.2015.10.01 9.

Hassali, M. A. et al. (2014) 'Does educational intervention improve doctors' knowledge and perceptionsof generic medicines and their generic prescribing rate? A study from Malaysia', SAGE Open Medicine, 2(2050312114555722), pp. 1-8.

Hohmann, N. et al. (2018) 'Association between Higher Generic Drug Use and Medicare Part D Star Ratings: An Observational Analysis', Health 
Policy Analysis. Elsevier Inc., 21(10), pp. 1186-1191. doi: 10.1016/j.jval.2018.03.005.

Howard, J. N. et al. (2018) 'Influencers of generic drug utilization: A systematic review', Research in Social \& Administrative Pharmacy. Elsevier Inc., 14(7), pp. 619-627. doi: 10.1016/j.sapharm.2017.08.001.

Kaplan, W. A. et al. (2012) 'Policies to promote use of generic medicines in low and middle income countries: A review of published literature, 2000 - 2010', Health policy. Elsevier Ireland Ltd, 106(3), pp. 211-224. doi:

10.1016/j.healthpol.2012.04.015.

Krisnadewi, A. K., Subagio, P. B. and Wiratmo, W. (2014) 'Evaluasi Standar Pelayanan Minimal Instalasi Farmasi RSUD Waluyo Jati Kraksaan Sebelum dan Sesudah Badan Penyelenggara Jaminan Sosial (BPJS) Kesehatan (Evaluation of Minimum Standards Pharmacy in Waluyo Jati Kraksaan Hospital Before and After Social Secur', e-Journal Pustaka Kesehatan, 2(2), pp. 192-198.

Lins Ferreira, V. et al. (2017) 'Generic drugs in times of economic crisis: Are there changes in consumer purchase intention?', Journal of Retailing and Consumer Services. Elsevier, 37(July), pp. 1-7. doi: 10.1016/j.jretconser.2017.02.008.

Maddox, C. et al. (2016) 'Factors influencing nurse and pharmacist willingness to take or not take responsibility for non-medical prescribing', Research in Social \& Administrative Pharmacy. Elsevier Inc, 12(1), pp. 41-55. doi: 10.1016/j.sapharm.2015.04.001.

Maxwell, S. R. (2016) 'Rational prescribing: the principles of drug selection', Clinical Medicine, 16(5), pp. 459-464.
Poon, S. J. et al. (2016) 'Usability of the Massachusetts Prescription', Academy Emergency Magazine, 23(4), pp. 406-414. doi: 10.1111/acem. 12905.

Sun, B. C. et al. (2017) 'Effect of Automated Prescription Drug Monitoring Program Queries on Emergency Department Opioid Prescribing', Annals of Emergency Medicine. American College of Emergency Physicians, 71(3), pp. 337-347. doi: 10.1016/j.annemergmed.2017.10.02 3.

Toverud, E.-L., Hartmann, K. and Ha'konsen, H. (2015) 'A Systematic Review of Physicians' and Pharmacists' Perspectives on Generic Drug Use: What are the Global Challenges?', Appl Health Econ Health Policy, 13(Suppl 1), pp. S35-S45. 